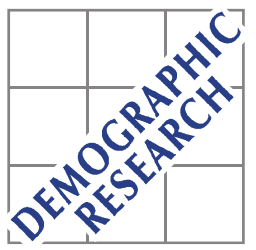

Demographic Research a free, expedited, online journal

of peer-reviewed research and commentary in the population sciences published by the Max Planck Institute for Demographic Research

Konrad-Zuse Str. 1, D-18057 Rostock · GERMANY

www.demographic-research.org

DEMOGRAPHIC RESEARCH

VOLUME 26, ARTICLE 10, PAGES 207-238

PUBLISHED 27 MARCH 2012

http://www.demographic-research.org/Volumes/Vol26/10/

DOI: 10.4054/DemRes.2012.26.10

Research Article

Family life and developmental idealism in Yazd, Iran

Mohammad Jalal Abbasi-Shavazi

Abbas Askari-Nodoushan

Arland Thornton

(C) 2012 Jalal Abbasi-Shavazi, Askari-Nodoushan \& Thornton.

This open-access work is published under the terms of the Creative Commons Attribution NonCommercial License 2.0 Germany, which permits use, reproduction \& distribution in any medium for non-commercial purposes, provided the original author(s) and source are given credit.

See http:// creativecommons.org/licenses/by-nc/2.0/de/ 


\section{Table of Contents}

$\begin{array}{lll}1 & \text { Introduction } & 208\end{array}$

2 Mechanisms for the spread of developmental idealism in Iran 212

3 Data and methods 215

$\begin{array}{lll}3.1 & \text { Research site } & 215\end{array}$

3.2 Sample design 216

$\begin{array}{lll}3.3 & \text { Data collection } & 217\end{array}$

$\begin{array}{lll}3.4 & \text { Data analysis } & 218\end{array}$

$4 \quad$ Results concerning distributions of developmental idealism beliefs $\quad 219$

4.1 Perceptions of the correlation between development and family attributes 219

4.2 Perceptions of the causal influence of development on families 220

4.3 Perceptions of the influence of lower fertility and older marriage on
development

4.4 Expectations about future family change 222

$5 \quad$ Results of analyses of predictors of beliefs in developmental idealism 223

6 Conclusion 225

$7 \quad$ Acknowledgements 229

$\begin{array}{ll}\text { References } & 230\end{array}$ 


\title{
Family life and developmental idealism in Yazd, Iran
}

\author{
Mohammad Jalal Abbasi-Shavazi ${ }^{1}$ \\ Abbas Askari-Nodoushan ${ }^{2}$ \\ Arland Thornton ${ }^{3}$
}

\begin{abstract}

\section{BACKGROUND}

This paper is motivated by the theory that developmental idealism has been disseminated globally and has become an international force for family and demographic change. Developmental idealism is a set of cultural beliefs and values about development and how development relates to family and demographic behavior. It holds that modern societies are causal forces producing modern families, that modern families help to produce modern societies, and that change is to be expected in the direction of the modern family.
\end{abstract}

\section{OBJECTIVE}

We examine the extent to which developmental idealism has been disseminated in Iran. We also investigate predictors of the dissemination of developmental idealism.

\section{METHODS}

We use survey data collected in 2007 from a sample of women in Yazd, a city in Iran. We examine the distribution of developmental idealism in the sample and the multivariate predictors of developmental idealism.

\section{RESULTS}

We find considerable support for the expectation that many elements of developmental idealism have been widely disseminated. Statistically significant majorities associate development with particular family attributes, believe that development causes change in families, believe that fertility reductions and age-at-marriage increases help foster development, and perceive family trends in Iran headed toward modernity. As predicted, parental education, respondent education, and income affect adherence to developmental idealism.

\section{COMMENTS}

Although our data come from only one city, we expect that developmental idealism has been widely distributed in Iran, with important implications for family and demographic behavior.

\footnotetext{
${ }^{1}$ Australian Demographic and Social Research Institute, Australian National University, Canberra, ACT 0200, Australia, and Department of Demography. University of Tehran, Iran.

E-mail: jalal.abbasi@anu.edu.au or mabbasi@ut.ac.ir.

${ }^{2}$ Faculty of Social Sciences, Yazd University, Iran.

${ }^{3}$ Population Studies Center, University of Michigan, USA.
} 


\section{Introduction}

In this paper we investigate the extent to which the beliefs and values of developmental idealism have been disseminated in one city of Iran. Our research is motivated by Thornton's $(2001,2005)$ theory that developmental idealism has been disseminated globally and has become an important force for family and demographic change. Developmental idealism is a set of cultural beliefs and values about development and how development relates to family and demographic behavior. It grows out of the modernization/development framework that has dominated much of social science and public policy for centuries (Mandelbaum 1971; Nisbet 1975/1969). Although the modernization/development model has, for many reasons, been heavily criticized recently as an academic and policy framework, its influence remains far-reaching in academia and public policy (Mandelbaum 1971; Nisbet 1975/1969; Wallerstein 1991).

The modernization model has for centuries posited societies as occupying different positions along a developmental ladder, with northwest Europe and its diasporas identified as modern or developed and other countries defined as traditional or less developed. The model tells people that they live in a dynamic world, with change moving from tradition towards modernity. The model specifies that the good life is found in northwest Europe and its overseas populations and that less-developed societies should model more advanced ones.

Developmental idealism draws from this modernization framework beliefs and values for living in the world. It states that societal attributes defined as modern are good and include such things as urban living, industrial production, and high levels of education and wealth. It also indicates that modern families are good and labels the following attributes as modern: individualism, autonomy of children, marriages arranged at mature ages by the prospective bride and groom, romantic love, nuclear families, equality between women and men, and planned and low fertility. In addition, several aspects of personal and family life such as divorce and non-marital sex, nonmarital cohabitation, and non-marital childbearing have become associated with modernity in recent decades, although they are often seen as negative rather than positive. Developmental idealism also includes reciprocal causal processes indicating that modern families help bring a developed society and that a developed society will result in modern families. Also, equality, freedom, and consent are specified as basic rights.

The globalization of developmental idealism is related to the spread of a world culture documented in an extensive body of research (Thomas et al. 1987; Meyer et al. 1997; Krücken and Drori 2009). World culture is a system of social institutions, beliefs, and values for organizing international relations, the state, legal systems, schools, and other activities. It emphasizes the importance of education, individualism, freedom, 
equality, justice, and human rights. It originated in the West, but has spread worldwide where it has been a powerful force affecting many things, including school attendance, school curriculums, support for human rights, campaigns to eliminate female circumcision, and the criminal regulation of sex (Benavot et al. 1991; Boyle 2002; Chabbott 2003; Tsutsui and Wotipka 2004; Baker and Letendre 2005; Cole 2005; Frank and Meyer 2007; Koo and Ramirez 2009; Meyer, Bromley, and Ramirez 2010; Frank, Camp, and Boutcher 2010).

The importance of the spread of developmental idealism is particularly relevant today because beliefs and values are increasingly seen as influencing family and demographic behavior (Lesthaeghe 1983; Cleland and Wilson 1987; van de Kaa 1987; Chesnais 1992; Mason 1997; Lesthaeghe and Neels 2002; Pearce 2002; Cunningham 2008; Yount and Rashad 2008). Cultural models provide frameworks for understanding the world and how it works, how people should live, and what things are good and how to achieve them (Geertz 1973; Fricke 1997). Johnson-Hanks and colleagues (2011) conceptualize culture and belief systems as schemas that are important for understanding families. Schemas exist both in the heads of individuals and in the beliefs and values shared in communities. Different schemas exist simultaneously, and these schemas can be contradictory and conflicting between societies, within societies, and within individuals. Schemas can vary in their legitimacy, salience, and power, with some schemas seldom being invoked. Schemas can also grow in legitimacy, salience, and power, so that seldom-used schemas can, over time, become important elements in decisionmaking.

The world's people have for centuries had their own schemas about how the world works, the goals to strive for, and appropriate ways for achieving goals. McDonald (1994) and Abbasi-Shavazi and McDonald (2008) have described such systems in regard to family life as idealized family moralities specifying what family attributes are good and moral. Developmental idealism contradicts many elements of historical family systems existing in many places, and as it comes into contact with such idealized family moralities, clashes of culture frequently emerge. Consequently, developmental idealism is usually not simply and quickly adopted, but more often is resisted and modified. Nevertheless, contact with developmental idealism often leads to substantial changes in such things as women's status, intergenerational relations, marriage, and childbearing.

Developmental idealism contradicts important elements of the idealized family morality historically existing in Iran. Families have for centuries been important elements of Iranian society. Families have been primary units for organizing nearly all of the social activities of life, including production, consumption, education, socialization, reproduction, leisure, and living arrangements. Historically, families in 
Iran were centers for warmth and affection, extended, and patriarchal. Establishing, maintaining, and continuing family units have been encouraged.

The Islamic value system has had a strong effect on family values and behaviours ever since the spread of Islam in Iran. Marriage and family harmony was emphasized, marriage was nearly universal, age at marriage was often low, and divorce was discouraged and infrequent. Interactions between men and women were specified by religious codes, and opportunities for premarital relationships were usually limited to short sessions of acquaintance that were strictly supervised by families and neighbors (Bauer 1984; Tashakkori and Thompson 1988). Marriage partners were chosen by parents with a preference for first-cousin marriage (Abbasi-Shavazi, McDonald 2008). Childbearing and procreation were encouraged.

Thornton (2005) has presented evidence that developmental idealism beliefs and values have spread widely among societal elites in many parts of the world, with international family planning programs and related efforts concerning reproductive rights and women's empowerment being especially poignant examples of their growing legitimacy and power (Donaldson 1990; Greenhalgh 1996; Barrett and Frank 1999; Berkovitch 1999; Luke and Watkins 2002; Chimbwete et al. 2005). There is also evidence from qualitative studies suggesting that ideas related to developmental idealism have spread among ordinary people in various international settings (Pigg 1992; Ferguson 1999; Liechty 2003; Deeb 2006; Osella and Osella 2006; Yount et al. 2010). However, there is a dearth of systematic survey evidence documenting the dissemination of developmental idealism among ordinary people.

Recent studies have begun to fill this gap. One study used survey data from Argentina, China, Egypt, Iran, Nepal, and the United States to document the dissemination of developmental idealism as it relates to fertility (Thornton et al. 2012). Two studies have documented endorsement of several aspects of developmental idealism in Nepal (Thornton, Binstock, and Ghimire 2008; Mitchell 2009). Also, a study in Argentina used questionnaire and focus group data to show widespread endorsement of many aspects of developmental idealism among high school students (Binstock and Thornton 2007; Thornton et al. 2008). Our paper furthers knowledge by studying the extent of its presence in one city in Iran.

Developmental idealism is a broad concept covering many aspects of personal and family life, making it impossible to evaluate all dimensions in a single paper. For this reason, we focus our investigation on a relatively small number of key elements of developmental idealism. We examine whether Iranians accept that family attributes defined as modern are associated with societal attributes defined as modern, that modern society is a force for bringing about modern families, and that modern families are forces for producing a modern society. We also examine to what extent Iranians expect that Iranian families will become more modern in the future. 
Our research is motivated by the general hypothesis that developmental idealism has been widely disseminated in Iran. Within this overarching hypothesis, we evaluate four specific hypotheses:

Hyp. 1: The majority of Iranians accept that family attributes defined as modern are associated with being a developed society.

Hyp. 2: The majority of Iranians accept that modern society is a force fostering modern families.

Hyp. 3: The majority of Iranians accept that modern families are forces for producing a modern society.

Hyp. 4: The majority of Iranians accept that Iranian families will become more modern in the future.

There have been many mechanisms for globalizing developmental idealism and the view of dynamic societies (Meyer et al. 1997; Thornton 2005; Krücken and Drori 2009). These include the mass media, education, the shift from rural agricultural societies to urban industrial societies, paid employment, and the distribution of scholarly and policy treatises about modernization. Social movements, including those for civil rights, women's equality, and fertility control, also spread developmental idealism. Many national and international governmental and nongovernmental organizations, including the United Nations, embrace and encourage elements of developmental idealism, as do many foreign aid programs.

In our research, we test several hypotheses about the effects of some of these factors on acceptance of developmental idealism. The hypotheses of this type that we examine include:

Hyp. 5: Growing up in an urban area, as opposed to a rural area, has a positive effect on acceptance of developmental idealism.

Hyp. 6: Childhood community resources have a positive effect on acceptance of developmental idealism.

Hyp. 7: Parent education has a positive effect on acceptance of developmental idealism.

Hyp. 8: Respondent education has a positive effect on acceptance of developmental idealism. 
Hyp. 9: Mass media has a positive effect on acceptance of developmental idealism.

Hyp. 10: Family income has a positive effect on acceptance of developmental idealism.

We evaluate these ten hypotheses using data collected from women living in Yazd, Iran in 2007. We evaluate Hypotheses 1-4 by examining the distributions of answers concerning acceptance of developmental idealism. We evaluate Hypotheses 5-10 by estimating multivariate ordinary least squares regression equations on developmental idealism beliefs.

Our research is important because no survey research has been reported concerning the prevalence of the beliefs of developmental idealism among Middle Eastern populations. Iran is especially relevant because it experienced several decades of modernization programs, yet during the last three decades has had an Islamic government that has positioned itself in opposition to the West. During recent decades Iran has experienced dramatic social change, including large declines in fertility and marked increases in education, especially among women.

We now turn to a discussion of the forces spreading developmental idealism in Iran. We then discuss data and methods, present findings, and end with a conclusion.

\section{Mechanisms for the spread of developmental idealism in Iran}

Over the past two centuries, many mechanisms have spread developmental idealism in Iran. Iran was never a colony of the West, but beginning in the $19^{\text {th }}$ century, European political and commercial expansion brought Iran into the European network of commerce. Contact with the West through educational institutions introduced new concepts, aspirations, occupations, and eventually a professional middle class. Numerous western concepts were introduced into the Iranian vocabulary, including development, progress, modernity, the rights of man, equality, freedom, liberty, parliament, and democracy (Abrahamian 1982).

Increased contact with the West and the spread of new ideas created desire for development (Azadarmaki and Bahar 2006, Saraie 2007). Adibi (1979) suggested that this enthusiasm for economic development necessitated educating a professional work force for political, industrial, and service occupations. This led to the establishment of more educational institutions in Iran and to many students obtaining education in Western countries. The result was an important increase in the number of educated and professional groups in the second half of the 19th century.

At the end of the $19^{\text {th }}$ and the beginning of the $20^{\text {th }}$ century, Iran experienced political and economic disorganization and the increasing dissemination of Western 
ideas of progress, constitutionalism, and nationalism (Foran 1993). Many intellectuals criticized the existing political structure as backward and argued that freedom and the rule of law were important for security and progress (Seyed-Rabie 2000), culminating in a Constitutional Revolution in 1905.

The development ideals and models that had spread during the 19th century were vigorously promulgated by the Pahlavi regime during its 54 years from 1925 to 1979 . The Pahlavi regime regarded the West as the pinnacle of development and as a model for social improvement. The cultural norms and ethical system of the West were treated by the Pahlavi regime as a substitute for long-standing religious and cultural values. Modernization was considered equivalent to Westernization, and tradition was viewed as equivalent to backwardness (Vatandoust 1985; Pirmoradi 2004). During this period Iran experienced major social, economic, and familial changes.

Reza Shah's regime (1925-1941) had modernization goals that included the expansion of communication and transportation networks, the establishment of secular educational institutions, and a new judiciary and administrative system. In his efforts to portray Iran as a modern nation, Reza Shah tried to abolish all visible symbols of the past, such as the veil and the native attire for men, and to replace them with Western dress and headgear (Abbasi-Shavazi and McDonald 2008). These initiatives paid little attention to social and religious sensitivities, and, as a result, veil banning received extensive opposition from the religious sector which treated it as an indication of ethical decline and a superficial imitation of Western appearance.

Mohammad Reza Shah (1941-1979) initiated an extensive set of reforms that aimed to redistribute agricultural land among farmers and to transform the economic organization of society, including the role of the family (Vatandoust 1985; AbbasiShavazi and McDonald 2008). One consequential impact of land reform was labor transfer from agricultural to non-agricultural sectors and the weakening of the family as a unit in economic production.

Mohammad Reza Shah's reform program made efforts to increase the status of women: granting women voting rights; reducing the unilateral rights of men to divorce; limiting the right of men to take a second wife; and giving women the right to divorce (Bahmani 2000). The custody of children after divorce became subject to the couple's agreement, and in cases of dispute, the courts could make the decision based on the best interests of the children. The minimum age at marriage without court consent was increased to 18 for females and 20 for males. These reforms were not implemented fully, but their symbolic value was important in officially recognizing certain rights of women (Makhlouf Obermeyer 1994; Hoodfar 1995).

To help achieve economic development, the government started a family planning program in 1967 that was implemented through financial incentives and the provision of information and contraceptive services. As a result of this program, some people, 
particularly in large cities, were able to prevent unintended pregnancies and to reduce family size.

Many government initiatives received criticism and resistance, especially from religious leaders. Many people regarded the initiatives as top-down Western-oriented cultural invasions against Islamic culture. After the 1979 Islamic Revolution many of the reforms were abolished, the family planning program was suspended, women's opportunities to work outside the home were restricted, and the school curriculum was revised to better reflect Islamic values. There was also a reduction of the minimum age at marriage, the elimination of the limitations on polygamy, and the provision of financial support for new couples.

Although the 1979 Islamic Revolution encouraged previous religious values, it did not mean overwhelming opposition to modernity. Instead, the desire to maintain longstanding cultural values was combined with demands for progress (Hetherington 1982). Soon after the revolution, the new government followed broad policies and programs to create a more equitable distribution of national resources among rich and poor and rural and urban.

One change in post-revolutionary Iran has been the expansion of education and the reduction in the gender enrolment gap. Because female educational expansion was sponsored by the Islamic government with the support of the clergy, previous opposition to female education was substantially weakened (Hoodfar and Assadpour 2000, 21). The literacy rate for women aged 15-19 in urban areas increased from around 57\% in 1966 to around $97 \%$ in 1996 and in rural areas from 5\% to 86\% (Abbasi-Shavazi and McDonald 2008, 185). In 2001, around 62\% of those admitted to government universities were women (Abdollahyan 2004). Aspirations and expectations of women in postrevolutionary Iran have also risen considerably (KianThiebaut 2002; Mir-Hosseini 2002; Shadi-Talab 2005). This has led to the increase in the status of women within the family and increased women's roles in family decision making.

After the revolution there was a gradual shift of values toward cultural elements and material values of Western societies (Rafi-Pour 1998). Furthermore, marriage, family formation, and childbearing attitudes and values experienced substantial changes (Mohseni 2000; Askari Nodoushan, Abbasi-Shavazi and Sadeghi 2009; Torabi and Baschieri 2010). Many of these attitudinal changes have been encouraged by government policies. For example, a decade after the revolution, the government began its own national family planning program to control population growth and to reach its development objectives. The family planning program has been very successful, with fertility decreasing from around 7.0 children per woman in the early 1980s to 1.9 in 2006 (Mirzaie 2005; Hosseini-Chavoshi, McDonald, and Abbasi-Shavazi 2007; Abbasi-Shavazi, McDonald, and Hosseini-Chavoshi 2009; Salehi-Isfahani, Abbasi- 
Shavazi, and Hosseini-Chavoshi 2010). Marriage and childbearing are now often delayed into the twenties.

\section{Data and methods}

\subsection{Research site}

Our data come from the city of Yazd, the capital of Yazd Province located in central Iran. During the last decades, as a result of rapid industrialization of the city, many migrants from both rural and urban areas have moved to the city. Its population grew rapidly from 64 thousand to 423 thousand between 1956 and 2006 (Bharier [1972] 1977, 337; Statistical Center of Iran 2006). About 99\% of the province's population are Muslims, most of whom are Shi'a and Persian.

Although we conducted our research in Yazd, we do not believe that a single city can represent all of Iran. Yazd is part of the larger Iranian society and has both similarities to and differences from other parts of Iran. One characteristic that makes Yazd a suitable site for our study is that it "epitomises the interface between tradition and modernity and their ensuing paradoxes" (Tremayne 2006). Yazd has a high level of industrial and socio-economic achievement, while also retaining a religious culture and many of its long-standing family elements from the past.

There are reasons to expect that developmental idealism is both more and less widespread in Yazd than elsewhere in Iran. Such indices as literacy, urbanization, industrialization, and women's labor force participation suggest that Yazd might have more exposure to developmental idealism than other areas. Yazd Province is above the country averages on each of these indicators, frequently ranking between first and fourth among all 30 provinces of Iran. (Ebrahimpour, 2010).

However, Yazd has a strong religious, moral, and family culture, suggesting that developmental idealism may be less endorsed in Yazd than elsewhere in Iran. Data from the 1999 national Iranian values and attitudes survey (Ministry of Culture and Islamic Guidance 2002) indicated that people in Yazd place more emphasis on religion than Iranians as a whole, as well as people in other provinces such as Isfahan and Tehran. Furthermore, people in Yazd place more emphasis on marriage and particularly early marriage (Abbasi-Shavazi, McDonald, and Hosseini-Chavoshi 2003; HosseiniChavoshi, Abbasi-Shavazi, and McDonald 2004). Comparisons across all 30 provinces

of Iran show that in 2006 Yazd Province ranked second lowest in female singulate mean age at first marriage. Yazd also has one of the lowest divorce rates in Iran. 


\subsection{Sample design}

Our data are drawn from individual survey interviews of women in Yazd. The sample was drawn using a two-stage stratified cluster sampling technique by the Statistical Centre of Iran. Interviews were held with one ever-married woman aged 15 - 59 in the sample households. For sample households that had never married women aged 15 29, one such woman was also interviewed (separately). Altogether, 548 ever-married women and 155 never-married women were interviewed, with an overall response rate of $97.2 \%$. This sample design produces unbiased estimates of the distribution of responses to our survey questions, and the exceptionally high response rate guarantees that non-response bias is virtually non-existent. Table 1 presents some demographic characteristics of the respondents.

Table 1: Demographic characteristics of survey respondents

\begin{tabular}{llcc}
\hline & & Number & Percent \\
\hline Marital Status & & 548 & 78.0 \\
& Ever married & 155 & 22.0 \\
Age-group & Never married & & \\
& $15-29$ & 274 & 39.0 \\
& $30-44$ & 246 & 35.0 \\
Education (years) & $45+$ & 183 & 26.0 \\
& $0-5$ & & \\
& $6-9$ & 196 & 27.9 \\
& $10-12$ & 117 & 16.7 \\
Employment & $13+$ & 239 & 34.0 \\
& & 151 & 21.5 \\
Birthplace & Employed & & \\
& Unemployed & 88 & 12.4 \\
Total & Urban & 615 & 87.6 \\
\hline
\end{tabular}




\subsection{Data collection}

Data were collected during November and December 2007 in face-to-face interviews. The survey questionnaire encompassed a wide variety of prospective and retrospective questions on such demographic and family issues as marriage, fertility, contraceptive use, and family related attitudes and values.

We designed three sets of questions to measure the respondents' views of the connections between development and family life. The first set focused on the perceived association between family attributes and development. We did not define development or specify where a developed place was located. Our second set of questions shifted the issue to causality and asked about the influence of a development program on family life in a low income, rural country with poor healthcare. The third set asked about the effects of programs to lower fertility and to increase age at marriage on socioeconomic outcomes.

The questions about the perceived association between family attributes and development were asked as follows: "Now, please think about what life is like today in countries that are not developed and compare it to what life is like today in countries that are developed. Please tell us whether each of the following things, in general, is more common in countries that are not developed or more common in countries that are developed."

The questions about the effects of a development program were asked as follows: "Now, please think about what life is like in a country where the standard of living is low, most people live in rural areas, and access to healthcare is poor. Suppose that country introduces a program to help make the country more developed. I will read a list of things this development program might change. For each one, please tell me whether it will increase in that country or decrease in that country once the development program has been successfully implemented."

The questions about the perceived effects of a program to reduce fertility were asked as follows: "Now, please think about what life is like today in a country where income is low, most people live in rural areas, access to healthcare is poor, and most couples give birth to at least six children. Suppose that country introduces a smallerfamily-size program to encourage couples to give birth to no more than three children. I will read a list of things this smaller-family-size program might change. For each one, please tell me whether it will increase in that country or decrease in that country once the smaller-family-size program has been successfully implemented.” A similar set of questions was asked about the consequences of instituting a successful older age at marriage program.

Our fourth set of questions asked about future trends in Iran to ascertain whether people think the future is headed towards or away from the family elements associated 
with modernity. The set of expectations questions was asked as: "Now please think about the next twenty years in Iran. Do you think (ITEM) will increase or decrease in Iran during the next twenty years?”

The independent variables in our multivariate analyses are standard survey measures. We measure respondents' birthplace as a dichotomy (rural equals zero and urban equals one), birth cohort in single years, parental education measured in average years of school for mother and father, own education in years of school, and family income in Iranian rials. We measured childhood community resources as an index from zero to six as follows: Respondents received code "1" if they had in their neighborhood before age 12 such services as primary school, guidance school, high school, health care centre and police station and received code 0 if they did not have access to such services before they were 12 years old. In another question they were asked about access to electricity in any places of living before age 12 and the same coding scheme was used. The index of childhood community resources is the sum of these dichotomous measures. Media exposure is also an index from zero to six and was calculated from the sum of the time respondents spent watching TV, listening to the radio, and reading magazines or newspapers which were each coded in an ordinal scale that ranged from 0 (low) to 2 (high).

\subsection{Data analysis}

We test our first four hypotheses by examining the univariate distributions of the four sets of dependent variables. We use a chi-square test to evaluate the hypotheses that each item has more than fifty percent of the respondents giving the developmental idealism answer.

We examine the hypotheses concerning the predictors of developmental idealism through a series of multivariate equations. We begin with Model 1 containing predictors that are clearly exogenous to an individual's views: birth cohort; birth place; childhood community resources; and parental education. Model 2 adds to Model 1 the respondent's own education, which is likely exogenous to developmental idealism acceptance. Model 3 adds family income and media exposure to Model 2. We add these two variables last because there may be a reciprocal influence of developmental idealism on them as well as them influencing developmental idealism. 


\section{Results concerning distributions of developmental idealism beliefs}

\subsection{Perceptions of the correlation between development and family attributes}

Table 2 presents respondent views on the distribution of family attributes between developed and not developed places. We indicate in bold the responses that accord with the writings of several generations of social scientists concerning the relationships between development and family structures.

Table 2: $\quad$ Percentage distribution of respondent perceptions of whether certain family attributes are more common in developed or not developed places

\begin{tabular}{|c|c|c|c|c|c|}
\hline & 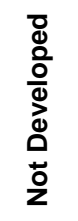 & 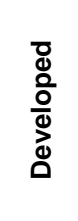 & 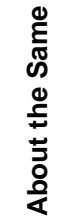 & $\chi^{2}$ & p-value \\
\hline Married children living with their parents or in-laws & 80.8 & 6.0 & 12.8 & 271.56 & .000 \\
\hline Females marrying before the age of eighteen & 81.9 & 7.1 & 10.8 & 288.46 & .000 \\
\hline Family unity and loyalty & 40.4 & 43.8 & 15.4 & -- & -- \\
\hline Elderly parents living with their adult children & 59.7 & 20.6 & 18.6 & 29.79 & .000 \\
\hline Arranged marriages & 86.3 & 9.0 & 4.7 & 373.22 & .000 \\
\hline Couples having many children & 95.0 & 1.8 & 3.0 & 572.58 & .000 \\
\hline Divorce and marriages breaking up & 38.1 & 47.2 & 14.5 & -- & -- \\
\hline Equality between women and men & 12.1 & 73.1 & 14.5 & 152.54 & .000 \\
\hline Babies born to unmarried mothers & 34.4 & 51.9 & 13.5 & -- & -- \\
\hline Opposite sex couples living together without being married & 26.7 & 64.3 & 8.5 & 59.45 & .000 \\
\hline Romantic love between a husband and wife & 17.4 & 56.0 & 26.5 & 10.54 & .005 \\
\hline Premarital sex & 24.2 & 56.8 & 18.8 & 13.42 & .001 \\
\hline Respect for elders & 48.8 & 35.0 & 15.9 & -- & -- \\
\hline
\end{tabular}

Note: For each item, the difference between $100 \%$ and the sum of the reported percentages is due to the item-missing data.

Table 2 confirms Hypothesis 1 for most items: the majority of Iranians report that family attributes defined as modern are associated with a developed society. For most items, the null hypothesis that fifty percent or less believe the hypothesized relationship is soundly rejected. More than $80 \%$ said that intergenerational coresidence of young people, young age at marriage, arranged marriage, and high fertility were more common in not-developed places, and $73 \%$ said that gender equality was more common 
in developed places. $12 \%$ or less gave the opposite answers on these items. It is clear that for these family attributes developmental idealism has been widely disseminated in Yazd. $^{4}$

For another 5 family items, the percentage giving the developmental idealism answer was between 52 and 64\%. These included the views that elderly parents living with their adult children was more common in not-developed places and that romantic love between a husband and wife and unmarried sex, unmarried cohabitation, and unmarried childbearing were more common in developed places, but the unmarried childbearing result is not statistically significant.

Family unity and loyalty, divorce, and respect for elders are the only items with less than fifty percent giving the expected developmental answer. However, it was only with family unity and loyalty that the number giving the answer predicted by developmental idealism is smaller than the percentage giving the opposite answer, and this difference is very small.

\subsection{Perceptions of the causal influence of development on families}

We now shift our focus from association to causality and the perceived effects of development on families (Table 3). These data provide extensive support for our second hypothesis, that the majority of Iranians believe that modern society fosters modern families. Much of the story for perspectives on the consequences of development is very similar to that for perspectives on the family-development correlation. As with the earlier reports of correlation, between 62 and $90 \%$ of the respondents said that development increases equality between men and women, increases romantic love between a husband and wife, and decreases co-residence, early marriage, arranged marriage and high fertility. Just half said that development would increase premarital sex.

Answers to three family items are in the opposite direction from the prediction of the developmental idealism framework. Whereas the developmental model suggests that development decreases family unity and loyalty and respect for elders, our

\footnotetext{
${ }^{4}$ The remarkable correspondence between respondent and scholarly reports of the correlation between development and these 5 family attributes is further highlighted by comparing the distribution of answers on these attributes with answers about the distribution of certain socioeconomic attributes (not shown in tables). The percentage saying that child mortality is higher in not-developed places and the percentage saying that a high standard of living, education, and women giving birth in hospitals is higher in developed places ranges between 79 and $90 \%$. The similar distributions on these 4 socioeconomic traits and the 5 family traits is remarkable because health, income, and education are three of the standard indicators used in many of the indicators of development used by international agencies, including the United Nations (United Nations Development Programme 2007/2008). Only 56\% said that the percentage of people working on farms was more common in not-developed places and $64 \%$ said that television was more common in developed places.
} 
respondents perceive the opposite. Similarly, the developmental model suggests that marital dissolution will increase with development, but our respondents tend to see the opposite. Note that these are the same three family attributes where there was no clear consensus of their relationship with development. The common thread in these three items is family solidarity and respect across generations and between husbands and wives. Yazd women, on average, do not see development reducing family solidarity and respect and may even see it producing more.

Table 3: Percentage distributions of responses about the effects of development on family attributes

\begin{tabular}{|c|c|c|c|c|c|}
\hline & 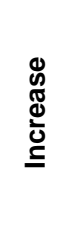 & 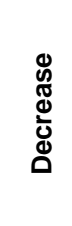 & 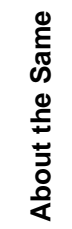 & $\chi^{2}$ & p-value \\
\hline Married children living with their parents or in-laws & 12.2 & 79.9 & 7.8 & 252.12 & .000 \\
\hline Females marrying before the age of eighteen & 16.1 & 78.8 & 5.1 & 233.32 & .000 \\
\hline Equality between women and men & 74.5 & 11.7 & 13.8 & 169.31 & .000 \\
\hline Family unity and loyalty & 58.3 & 29.2 & 12.2 & -- & -- \\
\hline Marriages breaking up & 39.7 & 52.9 & 7.0 & -- & -- \\
\hline Arranged marriages & 13.7 & 80.9 & 5.3 & 270.79 & .000 \\
\hline Couples having many children & 8.0 & 89.9 & 2.1 & 447.68 & .000 \\
\hline Respect for elders & 51.8 & 33.7 & 14.4 & -- & -- \\
\hline Romantic love between a husband and wife & 62.3 & 20.2 & 17.1 & 44.25 & .000 \\
\hline Premarital sex & 49.6 & 42.7 & 7.3 & -- & -- \\
\hline
\end{tabular}

\subsection{Perceptions of the influence of lower fertility and older marriage on development}

We next reverse the causal arrow between development and family by focusing on perceptions of the effects of fertility reduction and increasing age at marriage on several socioeconomic elements. As shown in Table 4, the data are generally consistent with Hypothesis 3 concerning modern families being forces producing a modern society. Between 75 and $94 \%$ said that reducing fertility and increasing age at marriage would increase the living standard, reduce infant mortality, and increase education. Between 63 and $72 \%$ said that reducing fertility and increasing marital ages would increase families having television. However, only about one-half said that reducing fertility and 
increasing age at marriage would reduce the fraction of people working on farms. Nevertheless, the number saying that these two family changes would reduce people working on farms was more than twice the number saying that they would increase farm employment.

Table 4: Percentage distribution of respondent perceptions concerning the effects of reducing fertility and increasing age at marriage on development

\begin{tabular}{|c|c|c|c|c|c|c|c|c|c|c|}
\hline & \multicolumn{3}{|c|}{ Reducing fertility } & \multicolumn{7}{|c|}{$\begin{array}{l}\text { Increasing age } \\
\text { at marriage }\end{array}$} \\
\hline & 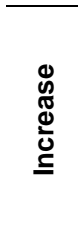 & 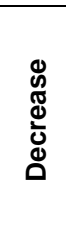 & 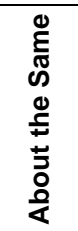 & $\chi^{2}$ & $\begin{array}{c}\mathrm{p}- \\
\text { value }\end{array}$ & 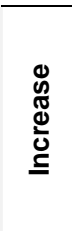 & 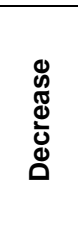 & 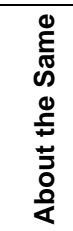 & $\chi^{2}$ & $\begin{array}{c}p- \\
\text { value }\end{array}$ \\
\hline Overall standard of living & 94.5 & 3.3 & 2.3 & 555.65 & .000 & 74.8 & 12.9 & 12.2 & 173.25 & .000 \\
\hline $\begin{array}{l}\text { Families having television } \\
\text { in their homes }\end{array}$ & 72.0 & 4.4 & 23.0 & 140.15 & .000 & 63.2 & 2.8 & 33.9 & 49.28 & .000 \\
\hline $\begin{array}{c}\text { The fraction of children dying } \\
\text { before their first birthday }\end{array}$ & 5.1 & 89.2 & 5.5 & 434.05 & .000 & 9.2 & 81.8 & 9.0 & 284.22 & .000 \\
\hline Being educated & 94.5 & 2.1 & 3.4 & 555.65 & .000 & 92.5 & 3.6 & 4.0 & 506.98 & .000 \\
\hline $\begin{array}{l}\text { The fraction of people } \\
\text { working on farms }\end{array}$ & 20.6 & 53.1 & 26.3 & -- & -- & 15.9 & 49.2 & 34.7 & -- & -- \\
\hline
\end{tabular}

Although the vast majority said that reducing fertility and increasing age at marriage are causal forces for socioeconomic change, the number seeing decreased fertility bringing change was greater than the number seeing increased age at marriage bringing change. For example, around $95 \%$ said that reducing fertility would increase the standard of living, while $75 \%$ said that increasing age at marriage would increase the standard of living. This difference may reflect, among other things, the fact that Iran has had a powerful government-led family planning program, while the government has tried to limit increases in age at marriage.

\subsection{Expectations about future family change}

We now shift our attention to expectations of future family trends. As documented in Table 5, the data are consistent with Hypothesis 4: An overwhelming majority view Iran as headed in the direction perceived as modern. A substantial majority (75\% or 
greater) said that all aspects of family life asked about will move in the direction seen as modern. This vast majority expected that age at marriage, divorce, status of women, and relationships between boys and girls prior to marriage would increase and that married couples living with parents or in-laws, the number of children, elderly people living with their adult children, and relative marriage will decrease in the next twenty years. These are substantial expectations for future family change that are consistently in the direction of family change seen as modern.

\section{Table 5: Percentage distribution of respondents' expectations about the} future of family change

\begin{tabular}{|c|c|c|c|c|c|}
\hline & 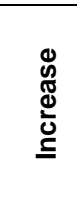 & 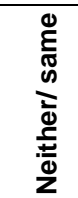 & 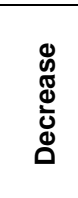 & $\chi^{2}$ & p-value \\
\hline Average age for a woman to first get married & 86.3 & 5.0 & 8.7 & 371.44 & .000 \\
\hline Married couples who live with their parents or in-laws & 7.5 & 3.1 & 89.3 & 434.05 & .000 \\
\hline Marriages ending in divorce & 76.7 & 3.7 & 19.5 & 200.60 & .000 \\
\hline Number of children a woman gives birth to & 6.6 & 2.0 & 91.5 & 482.51 & .000 \\
\hline Status of women & 94.7 & 2.0 & 3.3 & 560.81 & .000 \\
\hline Fraction of elderly parents who live with their adult children & 12.4 & 3.7 & 83.9 & 323.65 & .000 \\
\hline Relative (consanguineous) marriage & 7.4 & 17.8 & 74.7 & 172.51 & .000 \\
\hline Premarital relationships between unmarried boys and girls & 88.2 & 3.4 & 8.4 & 410.19 & .000 \\
\hline
\end{tabular}

\section{Results of analyses of predictors of beliefs in developmental idealism}

For our analysis of the predictors of developmental idealism, we constructed a composite dependent variable as the average number of answers that a respondent gave in the direction of developmental idealism. We did not include in this composite the items in Table 5 about the future, and we did not include any items in Tables 2, 3, and 4 when there was not a statistically significant majority giving the developmental idealism answer. The result was a scale taking the average of 24 dichotomous (0-1) items, with scores ranging from .29 to 1.0 , with a mean of .76 and a standard deviation of .15. 
Our first observation is that all bivariate correlations between our seven predictor variables are in the predicted direction (data not shown in tables). However, only four of these correlations are statistically significant: parental education; respondent's education; media exposure; and family income.

Our multivariate results are shown in Table 6. Hypotheses 7, 8, and 10 dealing with the effects of parental education, respondent education, and family income on developmental idealism are all supported. However, Hypotheses 5, 6, and 9 dealing with the effects of growing up in an urban place, childhood community resources, and media exposure are not supported by the data.

Table 6: Standardized regression coefficients of the effects of predictor variables on developmental idealism beliefs

\begin{tabular}{|c|c|c|c|}
\hline & Model 1 & Model 2 & Model 3 \\
\hline Birth cohort & -0.089 & $-0.141^{\star \star}$ & -0.078 \\
\hline Urban Birth Place & -0.030 & -0.040 & -0.050 \\
\hline Childhood community resources & 0.045 & -0.043 & -0.042 \\
\hline Parental Education & $0.230^{\star \star \star}$ & $0.118^{*}$ & 0.068 \\
\hline Respondent's Education & & 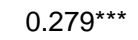 & $0.230 * * *$ \\
\hline Family income & & & $0.178^{\star \star \star}$ \\
\hline Media Exposure & & & 0.025 \\
\hline $\mathrm{R}^{2}$ & 0.040 & 0.076 & 0.105 \\
\hline F for Full Model & $6.933^{\star * *}$ & $10.742^{\star \star *}$ & $10.693^{\star \star *}$ \\
\hline
\end{tabular}

*** Sig. at $0.001 ;{ }^{* \star}$ Sig. at $0.01 ;{ }^{\star}$ Sig. at 0.05 .

Given the bivariate correlations, it is not surprising that the only statistically significant predictor of developmental idealism in Model 1 is parental education. Its effect is sizable, with each standard deviation increase in parental education having almost a one-quarter standard deviation effect on developmental idealism. The observed effects of birth cohort, birth place, and childhood community resources are not statistically significant. In Model 2, the added predictor, the respondent's own education, has a substantial effect on developmental idealism-more than a quarter standard deviation effect for each standard deviation of education. Of the two new variables added in Model 3, family income has a positive statistically significant effect of .18, while the coefficient for media exposure is small and statistically insignificant.

Most of the overall effect of parental education on developmental idealism is indirect, operating through respondent's education and family income. The parental education coefficient in Model 2 is about one-half as large as its coefficient in Model 1, suggesting that about one-half of its overall effect operates through respondent's 
education. The addition of family income in Model 3 reduces the effect of parental education even further (and to statistical insignificance), suggesting that some of the effect of parental education on developmental idealism operates through family income. Substantively, these results indicate that parental education has an effect on developmental idealism because it influences children's education (primarily) and children's family income (secondarily), which then influence the children's acceptance of developmental idealism. Once these indirect pathways are taken into account, there is little direct influence of parental education on children’s developmental idealism.

\section{Conclusion}

We began this paper with Thornton's $(2001,2005)$ theory that developmental idealism has been disseminated globally and become an important force for family and demographic change. We observed that while there is extensive evidence documenting widespread support for developmental idealism among the world's elites, there is little empirical evidence about it among ordinary people in everyday life. Our research was designed to investigate the extent to which developmental idealism has been disseminated among lay people in one city in Iran.

Our data overwhelmingly support Thornton's theory that many elements of developmental idealism have been generalized within Yazd, Iran. Many elements of Hypotheses 1, 2, 3, and 4 are supported by our data. Very large fractions of Yazd women associate development with family attributes, believe that development causes family change, and believe that fertility reduction and increase in age at marriage foster development. Remarkable numbers perceive family trends in Iran moving toward socalled modernity.

The evidence for Hypotheses 1 and 2 and the conclusion that Yazd women see modern families and modern societies related and development as an influence on family change is especially strong for six family items: gender equality, independent living early in marriage, late marriage, self-choice marriage, low fertility, and romantic love between spouses. This is strong support for the developmental idealism framework, as these six family attributes have been closely linked to development in the scholarly and policy literature for at least a century.

The data, however, also suggest that some family attributes are not connected in the expected way with development in the minds of women in Yazd. This is true for family solidarity where there is no clear consensus that family unity and loyalty, marital stability, and respect for elders are associated with either modernity or traditionality. Modest majorities also expected these things to increase with the introduction of a 
development program, the opposite from what the developmental idealism framework predicts.

Our data cannot reveal why Iranians associate most family elements with modernity in the way predicted by the developmental idealism framework, but do not associate other family elements with modernity in the predicted way. We speculate, however, that the factors disseminating developmental idealism, such as education and the mass media, have emphasized the connections between development and gender equality, independent living early in marriage, late marriage, self-choice marriage, low fertility, and romantic love between spouses more than the connections between development and family unity and loyalty, marital stability, and respect for elders. The difference could also lie in Iranian history and the ways in which Iranian culture historically evaluated well being and elements of family life. It may also be a result of the policies and programs of the Iranian government emphasizing the value of certain family attributes following the 1979 revolution (Afshani, Askari-Nodoushan and Fazel 2009; Ministry of Culture and Islamic Guidance 2002; Shadi-Talab 2005). Finally, we cannot rule out methodological and conceptual issues in question wording and respondent interpretation affecting responses. Further research is needed to understand why Iranian women relate some aspects of family life to development and not others.

Hypothesis 3 was generally supported by the fact that substantial majorities perceive family change to be a cause of development. Both fertility decline and age at marriage increase are seen as producing greater development. The expectation that fertility decline would bring development is probably related to the extensive recent family planning program in Iran. We did not ask how other family changes would influence development and believe such questions would be of interest for future research.

The data suggest that perceptions of the connections of development with unmarried sex, unmarried cohabitation, and unmarried childbearing are quite complex. Consistent with Hypothesis 1, substantial majorities view these attributes as correlated with development. However, inconsistent with Hypothesis 2, only about one-half see a causal effect of development on premarital relations (respondents were not asked about the causal influence of development on unmarried cohabitation and childbearing). It is likely that these apparently contradictory data result from the different contexts of the correlational and causation questions. The correlation question referred to the correlation between premarital sex and development, in general, and it is possible that respondents were referring to Western countries when they said that premarital sex was associated with developed places. But, when they were asked about the results of a development program, they were asked to think of a low income and agricultural country that would have excluded Western countries from consideration. About onehalf expected that a development program in such countries would either have no effect 
on premarital sex or would reduce it. This suggests that women from Yazd are split on the effect of development on premarital sex, but are quite clear in perceiving premarital sex to be associated with the West.

This interpretation is similar to the interpretation that researchers have given to data from Egypt (Thornton et al. 2010). A sample of Egyptian women said that low morality is associated with development when the location of the development was not specified, but when they were asked about the impact of development on an agricultural low income place, the majority said that it would lead to higher morality. This, and other evidence from Egypt (Yount et al. 2010), suggest that there is high ambivalence about Western modernity and that many people conceptually separate modernity from the West. They see an association of modernity with morality, but an association of the West with immorality. A similar thing may be occurring in Iran, with premarital sex seen as associated with the West, but not with development. More research is needed to investigate this interpretation for Iran.

Hypothesis 4, that people perceive the world as dynamic and moving in the direction of modernity, is strongly supported by our data. An overwhelming majority perceived future family changes going in the direction that generations of scholars have labeled as modernity. Such expectations are relevant for how individual Iranians live in the present and prepare themselves and their children for the future.

Support for Hypotheses 5 through 10 is mixed. Contrary to Hypotheses 5 and 6, birth place and childhood community resources had no significant effects on developmental idealism acceptance. There is no evidence in our data that these avenues are important in spreading developmental idealism in Yazd, Iran. Furthermore, although exposure to the mass media is positively correlated with developmental idealism, contrary to Hypothesis 9, there is no effect in the multivariate analysis. Apparently, media exposure is correlated with developmental idealism only because it is also correlated with education and income which have significant effects.

Consistent with Hypotheses 7, 8, and 10, parental education, respondent's education, and family income are each important influences on developmental idealism, making them the primary conduits of developmental idealism beliefs that we have measured. We now also know that the influence of parental education is largely indirect through the respondent's education and family income.

Unfortunately, data limitations prevented examination of the full range of influences on developmental idealism beliefs. We have empirically identified some conduits, but others have not been studied. We advocate additional research on these other influences.

It is important to note that our data are about the schemas of ordinary people about the relationship between development and family life and not about actual family change and socioeconomic change and their interrelationships. Understanding the 
relationships between family change and socioeconomic change is important, but not addressed in this paper.

Also, our data are not appropriate for evaluating whether the developmental idealism schemas about family and development influence family decision-making and behavior. What we have shown is that developmental idealism schemas are widespread and available for use in decision-making. We expect that developmental idealism will combine with historical Iranian cultural schemas about the family and influence actual family behavior. We advocate for additional research showing how developmental idealism combines with other cultural schemas to influence family decision-making.

Similarly, our data are not appropriate for evaluating the part of Thornton's theory which states that the increases in developmental idealism have been important forces for family and demographic change. Our data are consistent with that hypothesis in many ways, but they cannot demonstrate a causal influence because they were collected in 2007, and cannot establish that developmental idealism had a causal influence on earlier family changes. Nevertheless, our results indicate that understanding of developmental idealism is widespread in Yazd and these beliefs and values are available to influence decisions and behavior.

Our survey data also do not indicate when developmental idealism was disseminated in Yazd. It may have arrived just before we conducted our survey, but that seems unlikely, as there is reason to believe that it was actively disseminated in Iran for much of the $19^{\text {th }}$ and $20^{\text {th }}$ centuries. Although some elements were opposed by the government after the 1979 revolution, other elements have been vigorously disseminated in the recent two decades. It is thus likely that knowledge and acceptance of developmental idealism have been increasing in Iran for a long time and may have played an important role in many family changes in the country.

It is important to note that while our research is motivated by a desire to understand the acceptance of developmental idealism nationally in Iran and beyond, our data come from only one city, Yazd. This makes it impossible to generalize directly from our data to the larger population of Iran. As we discussed above, some characteristics of Yazd suggest that this city may be above the average as regards developmental idealism, but other attributes suggest the opposite. Our expectation is that these features of Yazd may counter-balance each other, so that viewpoints in Yazd are probably not very different from elsewhere in Iran. These data from Yazd also add to the small but growing body of evidence-from both Argentina and Nepal-that many elements of developmental idealism have spread widely. Future research is required to investigate how closely Yazd fits with the rest of Iran and how widely developmental idealism has spread internationally.

The relevance of our findings is not limited to explaining past trends in family behavior, but in evaluating possible future trends. The commitment of individuals to 
many of the elements of developmental idealism indicates that these ideas will be important for future trends in Yazd and probably in Iran as a whole. The fact that so many women are expecting a wide array of family changes is likely to foster those changes or reduce motivations to mobilize against them.

We close with the observation that developmental idealism research is very new and there is much that we do not understand about this schema, and its endorsement or rejection. We have already mentioned the need for research beyond Yazd and beyond Iran to more international settings. We also believe that there is a need for more methodological work concerning developmental idealism-how to measure it and how to interpret the results. We also need to learn more about why some elements of developmental idealism are endorsed more than others and to measure the strength of endorsement as well as the ways in which such schemas are applied in life. Also important are additional data and analyses investigating which individual, familial, and social factors encourage people to accept, modify, or reject developmental idealism. We also need research concerning how and under what conditions developmental idealism influences actual levels and trends in various family attributes.

\section{Acknowledgements}

This paper has benefited from the support of many individuals and organizations. We especially appreciate the support of the Deputy for Research of the University of Tehran and the Eunice Kennedy Shriver National Institute of Child Health and Human Development (R37-HD-039425). We thank Judy Baughn and Amanda Schuetz for administrative support and preparation of the manuscript. We also appreciate the contributions by the interviewers and respondents in the survey that provides our data. Also appreciated are the comments from the editor and anonymous reviewers on an earlier version of this manuscript. The authors remain responsible for any errors of omission and commission. 


\section{References}

Abbasi-Shavazi, M.J. and McDonald, P. (2008). Family Change in Iran: Religion, Revolution, and the State. In: Jayakody, R., Thornton, A., and Axinn, W. (eds.). International Family Change: Ideational Perspectives. New York: Taylor \& Francis Group: 177-198.

Abbasi-Shavazi, M.J., McDonald, P., and Hosseini-Chavoshi, M. (2003). Changes in family, fertility behavior and attitudes in Iran. Canberra: Australian National University. (Working Papers in Demography, No. 88).

Abbasi-Shavazi, M.J., McDonald, P., and Hosseini-Chavoshi, M. (2009). The Fertility Transition in Iran: Revolution and Reproduction. New York: Springer. doi:10.1007/978-90-481-3198-3.

Abdollahyan, H. (2004). The generations gap in contemporary Iran. Journal of Welt Trends 44: 78-85.

Abrahamian, E. (1982). Iran between Two Revolutions. Princeton, New Jersey: Princeton University Press.

Adibi, H. (1979). New Middle Class in Iran. Tehran: Society Publication Co. (In Persian).

Afshani, A., Askari-Nodoushan, A., and Fazel, S. (2009). Reproduction of gender roles in Farsi textbooks of Iranian primary schools. Women's Research Journal 7(1): 87-107. (In Persian).

Askari-Nodoushan, A., Abbasi-Shavazi, M.J., and Sadeghi, R. (2009). Mothers, daughters, and marriage: Intergenerational differences in marriage attitudes in the city of Yazd, Iran. Women's Strategic Studies (KETABE ZANAN) 44: 7-36. (In Persian).

Azadarmaki, T. and Bahar, M. (2006). Families in Iran: Changes, challenges, and future. Journal of Comparative Family Studies 37(4): 589-607.

Bahmani, E. (2000). Confrontation of family with modernism with emphasis on legal aspects. [MA thesis], Tehran: University of Tehran, Department of Sociology. (In Persian).

Baker, D.P. and Letendre, G.K. (2005). National Differences, Global Similarities: World Culture and the Future of Schooling. Stanford, CA: Stanford University Press. 
Barrett, D. and Frank, D.J. (1999). Population control for national development: From world discourse to national policies. In: Boli, J. and Thomas, G.M. (eds.). Constructing world culture: International nongovernmental organizations since 1875. Stanford, California: Stanford University Press.

Bauer, J. (1984). New Models and Traditional Networks: Migrant Women in Tehran. In: Fawcett, J.T., Khoo, S., and Smith, P. (eds.). Women in the Cities of Asia: Migration and Urban Adaptation. Boulder, Colorado: Westview Press.

Benavot, A., Cha, Y., Kamens, D., Meyer, J.W., and Wong, S. (1991). Knowledge for the masses: World models and national curricula, 1920 - 1986. American Sociological Review 56(1): 85-100. doi:10.2307/2095675.

Berkovitch, N. (1999). The Emergence and Transformation of the International Women's Movement. In: Boli, J. and Thomas, G.M. (eds.). Constructing World Culture: International Nongovernmental Organizations since 1875. Stanford, CA: Stanford University Press.

Bharier, J. ([1972] 1977). The Growth of Towns and Villages in Iran, 1900-66. In: Momeni, J.A. (ed.). The Population of Iran: A Selection of Readings. Honolulu: East-West Population Institute.

Binstock, G. and Thornton, A. (2007). Knowledge and use of developmental thinking about societies and families among teenagers in Argentina. Demografia 50(5): 75-104.

Boyle, E.H. (2002). Female Genital Cutting: Cultural Conflict in the Global Community. Baltimore: The Johns Hopkins University Press.

Chabbott, C. (2003). Constructing Education for Development: International Organizations and Education for All. New York: Routledge Falmer.

Chesnais, J. (1992). The demographic transition: Stages, patterns, and economic implications. Oxford: Oxford University Press.

Chimbwete, C., Watkins, S.C., and Zulu, E.M. (2005). The evolution of population policies in Kenya and Malawi. Population Research and Policy Review 24(1): 85-106. doi:10.1007/s11113-005-0328-5.

Cleland, J. and Wilson, C. (1987). Demand theories of the fertility transition: An iconoclastic view. Population Studies 41(1): 5-30. doi:10.1080/ 0032472031000142516. 
Cole, W.M. (2005). Sovereignty relinquished? Explaining commitment to the international human rights covenants, 1966 - 1999. American Sociological Review 70(3): 472-495. doi:10.1177/000312240507000306.

Cunningham, M. (2008). Influences of gender ideology and the gendered division of household labor on women's employment over the life course. Social Science Research 37(1): 254-267. doi:10.1016/j.ssresearch.2007.01.003.

Deeb, L. (2006). An Enchanted Modern: Gender and Public Piety in Shi i Lebanon. Princeton: Princeton University Press.

Donaldson, P.J. (1990). Nature against us: The United States and the world population crisis, 1965-1980. Chapel Hill: The University of North Carolina Press.

Ebrahimpour, S. (2010). Ranking of the provinces of Iran based on human development indices in 1996 and 2006. [MA thesis] Yazd, Iran: Yazd University, Department of Sociology. (In Persian).

Ferguson, J. (1999). Expectations of Modernity: Myths and Meanings of Urban Life on the Zambian Copperbelt. Berkeley: University of California Press.

Foran, J. (1993). Fragile Resistance: Social Transformation in Iran from 1500 to the Revolution. Boulder, Colorado: Westview Press.

Frank, D.J., Camp, B.J., and Boutcher, S.A. (2010). Worldwide trends in the criminal regulation of sex, 1945 - 2005. American Sociological Review 75(6): 867-893. doi:10.1177/0003122410388493.

Frank, D.J. and Meyer, J.W. (2007). University expansion and the knowledge society. Theory and Society 36(4): 287-311. doi:10.1007/s11186-007-9035-z.

Fricke, T. (1997). The uses of culture in demographic research: A continuing place for community studies. Population and Development Review 23(4): 825-832. doi:10.2307/2137383.

Geertz, C. (1973). The Interpretation of Cultures. New York: Basic Books.

Greenhalgh, S. (1996). The social construction of population science: An intellectual, institutional, and political history of twentieth-century demography. Comparative Studies in Society and History 38(1): 26-66. doi:10.1017/ S0010417500020119.

Hetherington, N.S. (1982). Industrialization and revolution in Iran: Forced progress or unmet expectation? Middle East Journal 36(3): 362-373. 
Hoodfar, H. (1995). Population policy and gender equity in post-revolutionary Iran. In: Obermeyer, C. (ed.). Family, Gender, and Population in the Middle East. Cairo: American University in Cairo.

Hoodfar, H. and Assadpour, S. (2000). The politics of population policy in the Islamic Republic of Iran. Studies in Family Planning 31(1): 19-34. doi:10.1111/j.17284465.2000.00019.x.

Hosseini-Chavoshi, M., Abbasi-Shavazi, M.J., and McDonald, P. (2004). Women's Autonomy and Reproductive Behavior in Iran. Paper presented at the 12th Biennial Conference of the Australian Population Conference, Canberra, September 15-17, 2004.

Hosseini-Chavoshi, M., McDonald, P., and Abbasi-Shavazi, M.J. (2007). Fertility and contraceptive use dynamics in Iran: Special focus on low fertility regions. Canberra: Australian National University (Australian Demographic and Social Research Institute Working Papers, No. 1).

Johnson-Hanks, J.A., Bachrach, C.A., Morgan, S.P., and Kohler, H.-P. (2011). Understanding Family Change and Variation: Toward a Theory of Conjunctural Action. New York: Springer. doi:10.1007/978-94-007-1945-3.

Kian-Thiebaut, A. (2002). Women and the making of civil society in post-Islamist Iran. In: Hooglund, E. (ed.). Twenty years of Islamic revolution: Political and social transition in Iran since 1979. Syracuse: Syracuse University Press.

Koo, J.W. and Ramirez, F.O. (2009). National incorporation of global human rights: worldwide expansion of national human rights institutions, 1966 - 2004. Social Forces 87(3): 1321-1353. doi:10.1353/sof.0.0167.

Krücken, G. and Drori, G.S. (2009). World Society: The Writings of John W. Meyer. Oxford: Oxford University Press.

Lesthaeghe, R. (1983). A century of demographic and cultural change in Western Europe: An exploration of underlying dimensions. Population and Development Review 9(3): 411-435. doi:10.2307/1973316.

Lesthaeghe, R. and Neels, K. (2002). From the first to the second demographic transition: An interpretation of the spatial continuity of demographic innovation in France, Belgium, and Switzerland. European Journal of Population 18(4): 325-360. doi:10.1023/A:1021125800070.

Liechty, M. (2003). Suitably Modern: Making Middle-Class Culture in a New Consumer Society. Princeton: Princeton University Press. 
Luke, N. and Watkins, S.C. (2002). Reactions of developing-country elites to international population policy. Population and Development Review 28(4): 707-733. doi:10.1111/j.1728-4457.2002.00707.x.

Makhlouf Obermeyer, C. (1994). Reproductive choice in Islam: Gender and state in Iran and Tunisia. Studies in Family Planning 25(1): 41-51. doi:10.2307/ 2137988.

Mandelbaum, M. (1971). History, man, and reason: A study in nineteenth-century thought. Baltimore: The Johns Hopkins Press.

Mason, K.O. (1997). Explaining fertility transitions. Demography 34(4): 443-454. doi:10.2307/3038299.

McDonald, P. (1994). Convergence or Compromise in Historical Family Change? In: Berquo, E. and Xenos, P. (eds.). Family Systems and Cultural Change. Oxford: Clarendon Press.

Meyer, J.W., Boli, J., Thomas, G.M., and Ramirez, F.O. (1997). World society and the nation-state. American Journal of Sociology 103(1): 144-181. doi:10.1086/ 231174.

Meyer, J.W., Bromley, P., and Ramirez, F.O. (2010). Human rights in social science textbooks: Cross-national analyses, 1970 - 2008. Sociology of Education 83(2): 111-134. doi:10.1177/0038040710367936.

Ministry of Culture and Islamic Guidance (2002). Iranian Values and Attitudes: Findings from a Survey in 28 Iranian Provinces. Tehran: Ministry of Culture and Islamic Guidance Publication.

Mir-Hosseini, Z. (2002). Religious modernists and the "woman question". In: Hooglund, E. (ed.). Twenty years of Islamic revolution: Political and social transition in Iran since 1979. New York: Syracuse University Press.

Mirzaie, M. (2005). Swings in fertility limitation in Iran. Critique: Critical Middle Eastern Studies 14(1): 25-33. doi:10.1080/10669920500056973.

Mitchell, C. (2009). Three essays on worldviews, autonomy and the family in Nepal. [PhD Dissertation]. University of Michigan, Department of Sociology, Rackham Graduate School.

Mohseni, M. (2000). A Survey on Socio-cultural Attitudes in Iran. Tehran: Ministry of Culture. (In Persian). 
Nisbet, R.A. ([1969] 1975). Social change and history. New York: Oxford University Press.

Osella, F. and Osella, C. (2006). Once upon a time in the West? Stories of migration and modernity from Kerala, South India. Journal of the Royal Anthropological Institute 12(3): 569-588. doi:10.1111/j.1467-9655.2006.00353.x.

Pearce, L.D. (2002). The influence of early life course religious exposure on young adults' dispositions toward childbearing. Journal for the Scientific Study of Religion 41(2): 325-340. doi:10.1111/1468-5906.00120.

Pigg, S.L. (1992). Inventing social categories through place: Social representations and development in Nepal. Comparative Studies in Society and History 34(3): 491513. doi:10.1017/S0010417500017928.

Pirmoradi, S. (2004). Iranian family. Journal of Better Health 4-5: 121-136. (In Persian).

Rafi-Pour, F. (1998). Development and Contrast: Essays Analysing the Islamic Revolution and Social Problems in Iran. Tehran: Entechâr Publishers Co. (In Persian).

Salehi-Isfahani, D., Abbasi-Shavazi, M.J., and Hosseini-Chavoshi, M. (2010). Family planning and fertility decline in rural Iran: The impact of rural health clinics. Health Economics 19(S1): 159-180. doi:10.1002/hec.1613.

Saraie, H. (2007). Family and it's evolution in the context of the demographic transition in Iran. Journal of Population Association of Iran 1(2): 37-60.

Seyed-Rabie, F. (2000). A study on the social determinants of family transition from extended to nuclear forms in contemporary history of Iran. [MA thesis]. Tehran: The University of Tehran, Department of Sociology.

Shadi-Talab, J. (2005). Iranian women: Rising expectations. Critique: Critical Middle Eastern Studies 14(1): 35-55.

Statistical Center of Iran (2006). Results of Labour Force Survey, Winter 2006. Tehran: Statistical Centre of Iran.

Tashakkori, A. and Thompson, V.D. (1988). Cultural change and attitude change: An assessment of postrevolutionary marriage and family attitudes in Iran. Population Research and Policy Review 7(1): 3-27. doi:10.1007/BF00241760. 
Thomas, G., John, M., Meyer, W., Ramirez, F.O., and Boli, J. (1987). Institutional Structure: Constituting State, Society, and the Individual. Newbury Park: Sage Publications.

Thornton, A. (2001). The developmental paradigm, reading history sideways, and family change. Demography 38(4): 449-465. doi:10.1353/dem.2001.0039.

Thornton, A. (2005). Reading History Sideways: The Fallacy and Enduring Impact of the Developmental Paradigm on Family Life. Chicago: University of Chicago Press.

Thornton, A., Achen, A., Barber, J.S., Binstock, G., Garrison, W.M., Ghimire, D.J., Inglehart, R., Jayakody, R., Jiang, Y., de Jong, J., King, K., Lesthaeghe, R.J., Mehanna, S., Mitchell, C., Moaddel, M., Ofstedal, M.B., Schwarz, N., Wang, G., Xie, Y., Yang, L.S., Young-DeMarco, L.C., and Yount, K. (2010). Creating Questions and Protocols for an International Study of Ideas about Development and Family Life. In: Braun, M., Edwards, B., Harkness, J.A., Johnson, T., Lyberg, L., Mohler, P., Pennell, B.E., and Smith, T.W. (eds.). Survey Methods in Multinational, Multiregional and Multicultural Contexts. Hoboken, New Jersey: John Wiley and Sons. doi:10.1002/9780470609927.ch4.

Thornton, A., Binstock, G., and Ghimire, D. (2008). International dissemination of ideas about development and family change. In: Jayakody, R., Thornton, A., and Axinn, W. (eds.). International Family Change: Ideational Perspectives. New York: Lawrence Erlbaum Associates, Taylor \& Francis Group.

Thornton, A., Binstock, G., Yount, K., Abbasi-Shavazi, M.J., Ghimire, D., and Xie, Y. (2012). International fertility change: New data and insights from the developmental idealism framework. Demography. doi:10.1007/s13524-0120097-9.

Torabi, F. and Baschieri, A. (2010). Ethnic differences in transition to first marriage in Iran: The role of marriage market, women's socio-economic status, and process of development. Demographic Research 22(2): 29-62. doi:10.4054/ DemRes.2010.22.2.

Tremayne, S. (2006). Modernity and early marriage in Iran: A view from within. Journal of Middle East Women's Studies 2(1): 65-94. doi:10.2979/ MEW.2006.2.1.65.

Tsutsui, K. and Wotipka, C.M. (2004). Global civil society and the international human rights movement: Citizen participation in human rights international 
nongovernmental organizations. Social Forces 83(2): 587-620. doi:10.1353/ sof.2005.0022.

United Nations Development Programme (2007/2008). Human development report: Overcoming Barriers: Human Mobility and Development.

van de Kaa, D.J. (1987). Europe’s second demographic transition. Population Bulletin 42(1): 1-59.

Vatandoust, G.R. (1985). The Status of Iranian Women During the Pahlavi Regime. In: Fathi, A. (ed.). Women and the Family in Iran. Leiden, Netherlands: E.J. Brill.

Wallerstein, I. (1991). The modern world-system as a civilization. In: Wallerstein, I. (ed.). Geopolitics and geoculture: Essays on the changing world-system. Cambridge: Cambridge University Press.

Yount, K.M. and Rashad, H. (2008). Family in the Middle East: Ideational Change in Egypt, Iran, and Tunisia. Oxford: Routledge.

Yount, K.M., Thornton, A., Mehanna, S., and Patel, S. (2010). Lay Accounts of 'Modern' and 'Traditional' Family in Greater Cairo: A Test of Developmental Models of Family Life. Paper presented at the Symposium on the Globalization of Modernization Theory: Clashes of Modernities and Moralities, University of Michigan, June 9-10, 2010. 
Abbasi-Shavazi, Askari-Nodoushan \& Thornton: Family life and developmental idealism in Yazd, Iran 